puration may take place in the haematocele, and Incision and dralnage per vaginam may become necessary. Gradual absorption of a pelvic haematocele does not always occur, even though the patient may be kept ander the most favourable/conditions. It sometimes happens that further attacks of pain occur, with increase in size of the abdominal swelling. Tais enlargement of the haematocele means further haemorrhage Into the sac, and In such cases it is usually found that the tubal mole is atill retained within the tube, and remains a source of danger to the patlent. Abdominal section, with removal of the affected tube and blood clot, will then become necessary.

In the third and last type of case, in which the patient has repeated attacks of paln, together wlth irregular haemorrhaglc discharge, but withont any collapse or falntness, and where a unilateral swelling is found in the situation of the tubs and ovary, it is always advisable to advise abdominal section, as there is grave risk of rupture of the gestation eac, or of severe haemorrhage occurring through the fimbriated end of the tube. If the operation is performed whlle there is a comparatively amall localized swelling In the situation of the tube there is, under present conditions of surgery, the least possible rick. If, however, the case is left and sudden severe haemorrhage into the peritoneal cavity occurs later, operative interference may become necessary when the condition of the patient is far:less favourable.

To sum up, one may say that operative treatment is indicated in those cases where the haemorrhage is moderate or severe and of recent origin, and also where the symptoms and physical signs indicate that the gestation sac is still contained wlthin the tube. It is sale, however, to wait and watch the patlent in cases where a haematocele has already formed, and where, after the Inltial attack of pain, the patient has been free from symptoms for a week or more. Under these circumstances there is a good chance of the blood becoming completely absorbed, and no serious risk is run by lollowing an expectant treatment.

\section{A CASE OF RUPTURED ECTOPIC GESTATION}

\section{OCCURRING IN A RUDIMENTARY HORN}

\section{OF A UTERUS BICORNIS UNICOLLIS.}

\section{B又 H. T. HICKS, F.R.C.S.ENG.}

GYNAECOLOFICAL SURGEON TO THE DERBYSHIRE ROYAL INFIRMARY, DERBY ; LATE OBSTETRIC REGISTRAR AND TUTOR, GUY' HOSPITAL: AND ASSISTANT SURGEON TO

$$
\text { THE SAMARITAN HOSPITAL. }
$$

History of the Cask.

R. P., aged 39, had had three full-term children, the youngest being 16 years old. Nine years ago the patient had an attack of peritonitis on the right side which was thought to be due to appendicitis. Nine weeks before admission Into the Samaritan Hospital she was selzed with sudden sbdominsl pain on the left side when fourteen days over. due with a mengtrual perlod. Haemorrbage from the vaglna began a week later. The patient only $r \varepsilon$ mained in bed a few days after the onset of pain; and did not consult her doctor till nearly six weeks later. During this time the pain continued, and eventually became worse. She then went to see Dr. Hamlll on of Ashford, who found the uterine tumour. Except at the onset of the pain the patient did not seem to be 111 , and merely went to the dostor bectruse the pain con-

tinued and prevented her dolng her work. Dr. Hamilton sent the patient to see me, and she was admitted into the Samaritan Hospital under my care.

On examinstion I could feel the somewhat rounded firm tumour attached firmly to the left side of the nterus, and I at first thought that it was a fibrold, and that the patient might possibly have aborted nine weeks earlier.

On further consideration, however, there seemed to be too much pain present for a simple fibroid tumour; and the suddenness of the onset, followed a few days later by uterine haemorrhage, strongly suggested a ruptured ectopic gestation. With this possibllity in view I advised operation, which the patient was only too ready to accept, because she cald the pain was at times more than she could bear.

On opening the abdomen the uterus was found to be enlarged; the projecting left horn contalning the mole was firmly attached to the intestines and omentum. The right Fallopian tube was converted Into a large bydrocalpinx. I removed the uterus by supravaginal bysterectomy as well as the right tube and ovary. The left tube was quite normaland its timbriated end patent. The left tabe and ovary were not taken away. The only point of interest about the operation was the condition of the intestines, whlch were firmly attached to the site of rupture on the posterior aspect of the gestation sac. The walls of the gut in direct relation to the ruptured gestation sac were nearly half an inch thick. This was due to haemorrhage which had taken place into the muscular cost of the intestine. A portion of the lleum which capped the blood clot had a crater-like depression nearly half an inch deep The lamen of the gut was not encroached upon. I had considerable difficulty in freelng the two adberent and thickened loops of emall intestine and the slgmoid. The peritoneal cont of the gat had completely disappeared over the adherent area and it was quite Impossible to bring the peritoneum together, but the eroded and thickened walls were united 88 far as possible with catgat without constricting the intestinal canal. No doubt the trophoblasts of the ovum had actually invaded the gut and their eroding action had caused the haemorrhage into the muscular cost of the intestine.

The patient made an uneventiul recovery.

THE SPFolmin.

The uterus is enlarged, measuring $3 \frac{1}{2} \mathrm{In}$. vertically and $4 \frac{3}{4}$ in. and $3 \frac{1}{2}$ in. across at the levels of the attachments of the Fallopian tubes and round ligaments respectively. Externally it has the appearance of a uterus blcornis unlcollis, the right side being well developed and the left rudimentary. The rudimentary horn jolns the right side above the internal os, and is composed of a solld block of aterine muscle in the distal portion of which the mole has developed. The rudimentary horn projects upwards and to the left from its junction with the right side for a distance of $2 \frac{1}{2}$ in. and measures $1 \frac{3}{4}$ In. across at its base. The bridge of uterine muscle whlch separates the mole from the nterine cavity of the right slde is $1 \frac{1}{4} \mathrm{in}$. thick, and contrins $r o$ cavity. There is thus no connexion between the cavity of the uterus and that containing the mole. The mole measures $1 \frac{1}{4}$ by $2 \frac{1}{2}$ in. In its chief diameters. It - is composed of firm blood clot, and is surrounded by a rather thin capsule on its outer slde. The lelt Fallopian tube is attsched to the outer and lower Anterior view of specimen. Rt. F.T., Right Wallopian tube; Rt. O., right ovary:
C..., corpus luteum ; U.C, uterine cavity; Lit. R.L, left round ligament; $L^{t}$. F.T., cut angle of the horn. Behind the capsnle has given $x 87$ over an area about the size of a half crown, ard tbrorgh. the rupture blood clot protrudes. The top of tbe tlood olot is shown in the drawing of the spectimen. The left 
round ligament is attached to the front and outer aspect of the horn. The right side of the uterus is well developed, and the corresponding Falloplan tabe is converted into a hydrosalpinx. The right ovary shows. several haemorrhagic areas and a corpus luteum of pregnancy.

Microscopically, the mole consists of fibrin, in which chorionic villl are seen. The blood clot is in direct contact with the uterine muscle and the capsule. In a few places there, seems to be an attempt at some decidual formation immediately at the perlphery of the mole. The uterine cavlty. Is lined by normal mucous membrane, but there are decidusl cells in the stroms benesth the endometrium. Lurge quantities of lateln tissue surround the corpus lateum in the right ovary.

I think the specimen is best described as belng one of a ruptured ectopic gestation, which has developed in the muscle of a rudimentary left horn of a uterus blcornis. The ovum probably passed across the pelvic peritoneum from the right ovary and entered the left Fallopian tabe, and, becoming arrested in the blind nterine end of the tube, burrowed its way into the uterine muscle. It might posilbly be suggested that the blood had collected in the horn as the result of a unilateral haematometra. . This criticism of the speclmen is, of course, negatived by the microscoplcal examination of the mole and the clinical history of the case.

Mr. Shattock, who has made a very careful examination of the specimen, has found chorionic vill in the blood clot which is adherent to the peritoneum around the seat of rupture. This fact clearly shows that the intestines were in direct contact with the chorionic villi.

\section{RIGOR MORTIS IN THE STILLBORN}

By C. H. WATTS PARKINSON, M.R.C.8., L.S.A., D.P.H, CORONER FOR EAST DORSET.

The annotation in the British Medical Jodras of October 5th, 1907, on a case of rigor mortls in a atillborn infant, reported by Dr. Ulrich, of Erfurt, makes mention of the importance of this occurrence from a medico-legal point of view, and as I have reported simllar cases during the past thirty years, but cannot find any referencethereto in the varions works on medical jurlsprudence I have consulted, I venture again to relate the facts observed by myself, in the hope that being confirmed by the experience of others, they may now be considered, verified, and embodied in the recognized manuals for the instruction of students.

CASE I.

In 1874 g zonng woman of respectable familly living alone in a country schoolhouse was overheard by the old attendant woman (who suspected her condition) groaning in her room; after some time the young woman went out, and the attendant golng into the room found in a drawer the dead body of a child, newborn, and gave information to the pollce. A medical man was called, and the woman was committed for trial for murder. The old woman did not hear the child cry, but the medical man found lacerated wounds of the mouth, etc. He was asked if he had made a post-mortem examination, and said No, because there was strong rigor mortis, and this showed that the child was born alive. The woman was ably defended; the surgeon's neglect to examine the body, and the fact that the old woman listening heard no cry, strengthened the defence that the wounds were inflicted in the agony of expulsion, that the child was born dead, or died from want of attention, and not from the injuries, and she was convicted of concealment only.

Case II.

A short time after this case I was called to a multipara in the country, and found her in hard labour; the pains were regular and very violent; the child was allve. The pains, though severe, were not expulsive, and the membrane had been ruptured some time. Alter a time the pains ceased, and I went on a round. On my return I found the pains had commenced again; as progress was slow, I gent for my father to assist me, and we delivered her of a stillborn child with difficulty. We noticed that there wiss some stiffening of the limbs, and the child was laid aside while we attended to the mother, who was much exhausted. Belore leaving we examined the child and found that the rigidity we had noticed before had increased, and that there was strong rigor mortls, and that of an unusual kind, producing an attitude unlike that caused by ordinary cadaveric rigidity. The head was drawn forward and the back somewhat rounded; the arms were flexed on the elbows and bent on the chest. The thighs were drawn ap and flexed towards the belly, and the legs were flexed at the knees; in fact, the body was drawn up into the position in which it would lie in the aterus, as shown in the accompanying illustration from

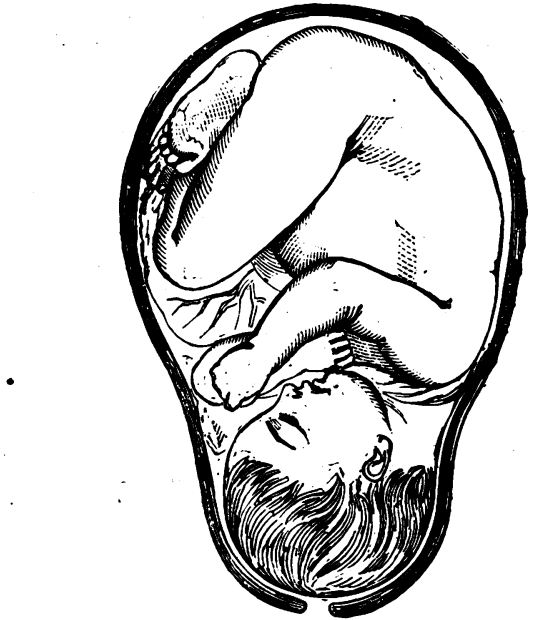
Fig. 1.-Adaptation of fetus to uterus. (By permission of Messrs
J. and A. Churchill.)

Dr. Tgler Smith's Marual of Obstetrics (Fig. 1). I reported thls case shortly in the Medical Times. Since then I have been on the look-out in cases of stillblrth, and the following two cases are fair examples.

Case III.

This was an example of extreme hydrocephalus; the patlent was a primipara, and delivery was effected with much difficulty after perforstion. The infant when born was quite flaccld, the limbs lying extended, but rigor mortis set in, and gradually the limbs were drawn up into the intrauterine position, as described above.

\section{Case IV.}

An unmarried glrl was suspected by the police and sub. sequently the body of a newly-born child was found in a hole in the garden in a box. The girl was confined at her home, and the parents stated that, as the child was born dead, they thought it unnecessary to register, and of course hoped to hide the daughter's shame. I was called on to examine the body. It was a well-developed child, somewhat prematurely born. It was lying doubled up in a cardboard box; on taking it out the limbs were limp, and on placing it on its back the arms and legs were extended In the ordinary way, but there were marks of pressure at the flexure of the arms and legs, and on taking up the body the limbs fell naturally into the intrauterine position. Eramination showed that the lungs had not been inflated, but were solld. As a result I was able to state that the parents' account was correct-that the child was born dead, and that it had died probably some days before it had been expelled, that rigor mortis had set in and passed off in utero before birth.

Conoutsions.

I regret that I cannot now give detalls of the dates and other particulars of these cases, but they will illustrate the conclusions I wish to enforce.

1. Rigor mortis may set in under certain conditions belore labour, and may pass off whlle the child is atlll in utero, and possibly may delay the birth in these cases untll it has passed away.

2. Rigor mortis may set in when the chlld dles during labour, and may either be complete before or may go on to completeness alter birth, and in these cases increases the difficulty of expulsion.

3. A chlld may die during labour and be expelled before rlgor mortis can set in, but rigor mortis may supervene after birth more or less completely.

4. The attitude produced by rigor mortis in stillborn children differs from that produced by cadaveric rigldits 